\title{
[34I ]
}

XL. Objervations on Mr. Maferes's View of the ancient Conftitution of the Englih Parliament, by Charles Mellin, Efquire. In a Letter to the Rev. Mr. Norris, Secretary to the Society of Antiquaries.

Read at the Society of Antiquaries, June 9, 1772.

IHAVE read with attention Mr. Maseres's View of the 1 ancient Confitution of the Englifh Parliament; and have received great information from the many ingenious remarks there made on a fubject confeffedly obfcure and intricate.

But as I have occafionally ventured, while that Paper was in reading, to throw out fome doubts with regard to particular doctrines there laid down, I have here collected, as more agreeable to the practice and wihes of the Society, the purport of what $I$ then offered; not that I mean, or wifh to be underftood, to enter the lifts with a gentleman of his fuperior abilities and knowledge; but only to fuggeft to his reflection fome authorities which may poffibly have efcaped his obfervation, and to offer fome opinions, which, however erroneous they may be, I have long fince adopted; but which $\mathrm{I}$ hall always be ready to renounce, whenever the principles on which they are founded are fhewn to be untenable.

As advocates for truth only, we are both aiming at the fame goal; I hope therefore what I may here offer as a free difcuffion and examination of this fubject and the doctrines laid down by Mr. Maferes will not be difpleafing to him. 
I PERFECTLY agree with Mr. Mareres, that William the Firft chimed the crown by a pretendedly legal title, the will of Edward the Confeffor $[a]$; to which he afterwards joined the confent of the land-holders; for fo I interpret what he calls the principal men. The latter, no doubt, was his beft title. But I cannot conceive that, though he thould have attempted to alter the rights of property which had obtained here before his time, he could be able to effectuate it; nor that a meafure fo replete with oppreffion would be adopted, where no reafon appears to juftify it. I am therefore not inclined to believe this opinion, whatever the prejudices and reprefentations of bigoted hiftorians may have fuggefted Let us take a view of the ftate of property before his time.

If we look into Tacitus $[b ;$, we thall there find the firf traces of our ancient Saxon government. I fay Saxon, becaufe I think rve need not go higher; though the laws of Howel Dhà feem to imply an imperfect feudal fyftem fubfifting even in the times of the Britons; concerning which Mr. Whitaker has written fully and learnedly in his Hiftory of Manchefter.

The Germans, from whom were derived our Saxon progenitors, were all warriors; all attendants on their prince, whofe glory it was magno femper electorum juvenum globo circumdari; in pace decus, in bello praefidium; and the prince was molt refpected, $\mathcal{i}$ numero et virtute comitatus emineat. Principes pro victoriâ pugnant, comites pro principe. Principem defendere, tueri, fua quoque fortia facta gloriae ejus alfgnare, praecipuum facramentum eft [c].

THIS is the earlieft account I have met with relative to this matter; and it in good meafure coincides with my idea of

[a] Hale's Hiff. C. L. $5^{\text {th }}$ ch. [b] De Mor. Germ. [c] Ibid. fealty. 


$$
\text { on the preceding Paper. }
$$

fealty. Tacitus continues, magnum comitatum non nifi vi belloque tueare; whence, as well as from the nature of things, I infer that the prince maintained his army ; but it appears to have been by war and rapine, whilft it continued in Germany, a poor country, and overftocked with inhabitants; materia munificentiae per bella et raptus. But when the Saxons bad gained a footing in this rich country, it is reafonable to fuppofe their fervices were no longer to be gratified and compenfated with the liberality of their prince, confined to the bellatorem equum, the cruentam victricemque frameam, as heretofore; they wanted more fubftantial marks of his favour; and, as in Germany, magna erat comitum aemulatio, quibus primuis apud principem fuum locus, thit fpirit could never fubfide by conqueft. I conclude therefore, that where-ever the German forces made conqueits in England, they enflaved the natives, and feized fuch part of the lands as they pleafed. Hence appears to me the origin of our pure villenage; concerning which 1 thall fpeak hereafter. Thus Montefquieu obferves [d], Les Francs avoient conquis; ils prirent ce qu'ils voulurent, et ne firent des reglemens qu'entre eux. And $[e] \mathrm{La}$ refiftance, la revolte, la prife des villes emportoient avec elles la ferviiude des babitans. It would be too long a digreffion to enter minutely into the property of the crown at the different periods in which German forces came into this country. Suffice it to fay, that the chief property in the feveral kingdoms belonged to the king of that kingdom, or his fub-tenants, and was confolidated under the monarchs of the Heptarchy. The converfion of allodial property into feudal increafed in appearance, though not in fact, the power of the crown. More land it is true appeared to be holden on feudal principles, but the allodial people $[f]$ were bound before to the civil
[d] L. $\mathrm{xxx}_{0}, \mathrm{c}, 7$.
[e] C. 2 .
[f] Wilkins L1. Alfred
L1. Cnut 54 
jurifdiction, and were punifhed with the lofs of life, and forfeiture of eflate, in cafe of high treafon.

I Do not fay that no acts of violence and oppreffion were committed by William the Firtt. I believe with Ingulphus that there were many; and that in the latter part of his reigu he did not promote the natives to offices of truft, upon the general principle in Curtius, $[g]$ quos viceris, cave amicos tibi credas; becaufe he found even Waltheof ungrateful, whom he had married to his niece. But as to their ancient property, it was left, for the moft part, as he found it, except where they forfeited their lands by confpiring againft him; in which cafe the laws of Alfred and Canute feemed to him to be on his fide [ $b]$. Slavery was prior to the Conqueft; lands defcended before the Conqueror's days; and Doomfday Book is, to me, an authentic proof, that he altered not the rights of property; it being, for the mott part, an account of the lands belonging to the crown in the time of Edward the Confeffor; and he alfo confirmed the rights of his fubjects by his $5 \mathrm{lt}$ law.

INDEED, as the crown had fo large a property of its own, increafed by the forfeitures, mentioned by $\mathrm{Mr}$. Maferes, and by the change of allodial into feudal lands, there feems lefs colour or neceffity for an arbitrary alteration of property. However, tho' I may differ from thi; gentleman as to the origin of pure flavifh villenage, which I conceive to have been grafted on the Saxon or Danifh conquefts; and as to the introduction of our fevdal tenures, which I take to have proceeded from the will of the lord of the foil, William I. who let the lands on the tenures of his country; I agree with him that we are to date the compleat introduction and eftablifhment of thofe Norman tenures from his time.

[g] Lib. VIr.

[b] See Ll. Cnut 5I, et pafjim, as to Slavery, and Ll, Alfred 37 as to Eftates。 See alfo Wilkins's account of the claim of the Starbwn Eamily, in his preface to the Laws of William I. 
I CONCUR in the idea that an.eftate to a man and bis beirs for ever was an eftate to him and his lineal defcendants, and not his collateral relations; for, as a feudum novum, it could defcend only to the blood of the firft purchafer; and the numerous deeds of confirmation by heirs which we meet with, prove that the anceftor could not bar the heir. Indeed the laws of Alfred gave the heir this right [i]. Hence it followed, that where the parties meant to curtail the heir of fuch right, they inferted the claufes beredibus, et beredibus beredum, vel cuicumque dare, vel vendere, vel legare, vel aliquo modo affignare voluerit; which, putting it in the option of the firt tenant to circumfcribe, and to bar his heirs, rendered the right of the heir of no value; and then, by degrees, the courts of law interpreted the gift to be to $A$ alone; and the words and bis beirs to mean only the quantum of the eftate given to A, which was for ever $[k]$. We are not to be furprized, if the heir thought he had a right ex dono; fince I was anked my opinion once in the country by a man who did not want fenfe, whether, where an eftate was given to $A$, and his heirs, A could bar his heirs.

Lit TLE difference, I obferve, is made by Mr. Maferes between Efcheat and Forfeiture for Treafon. 'So fays Fleta, quoties per defectum vel delictum extinguitur fanguis tenentis; and fo I ever have thought: but the courts of law have attempted great diftinctions in favour of prerogative, a word which had better be forgotten, being neither calculated for king nor people. It is too long a fubject for difcuffion on the prefent occafion. I will only fay, that I do not prefume to argue againft the diftinetion laid down in Lord Coke, and Salkeld, between the right of the king, holding as king, upon attainder for Treafon; and his right, as lord, in other efcheats. The cafe of the manor of Peverel, mentioned by Lord Coke, the opinion of fo great a judge and lawyer, and the two later cafes in

Efcheat and Forfeiture for Treafon.
[i] See L1. Alfred, 37• Vor. II.
[k] See Plowden.
[l] On 3I chap. of Magna Charta. Y y Salkeld,

Eftate to A, and his heirs. 
Salkeld, bar me from attempting fuch a plea; but I am not preclud-. ed thereby from giving my opinion as to the firft introduction of a prerogative under which Lord Huntingdon and divers of the ancient nobility at this day fmart ; and which has occafioned the extraordinary cafe of an elder brotijer, born before pardon by charter, who, on the death of his father, cannot inherit bis eftate: neither can the younger take it, though he has inberitable blood, during the life of his elder brother; but the eftate remains in abeyance till tine elder brother is pardoned, or dies. Indeed, during the prevalence of the Roman religion, if the younger brother could prevail on his elder to profefs, and mori civiliter, he might fucceed to the eftate. I fear much that this diftinction pays a compliment to the crown at the expence of the $3 \mathrm{Ift} \mathrm{ch}$. of Magna Charta. I wilh the crown lawyers would confider, that the ftate of property among us is now quite altered; we both give the produce of the land, which we hold, with more facility to the crown, than our anceftors gave theirs; and hold the fame land with more (if I may fo call it) allodial independance. Monarchy is now properly tempered with liberty ; and the fame feverity, which formerly in a warlike enthufiaftic people made the happinefs of government, is now the bane of it. The king cannot fecure his throne on a firmer bafis than on the liberty of his fubjects, which muft infure their love ; and we may now, with fafety to the ftate, revert to that excellent rule, I believe of the civil, I am fure of the common law, "That no one thall fuffer for a fault " which he is not proved to have committed; and till proof had, " he Thall be prefumed innocent."

Mr. Maferes, I obferve, blames the divifion among the daughters in coparcenary. If I miftake not, Feuds originally defcended to all the fons; and the book of Feuds fays fo. Certainly lands defcended in Gavel-kind among the ancient Britons; and Mr. Whitaker $[\mathrm{m}]$

[k] Hiftory of Manchefter, p. 25 I.

thinks 
thinks the plan of divifion of the eftates among all the fons, whilft the crown was hereditary, was creative of abfolute authority; as the crown could have been in no fear of oppofition from the greatnefs or the exorbitancy of an overgrown fortune in any of the barons. Mr. Maferes, fpeaking of the Norman fyftem, thinks it the moft perfect and durable of all fyftems of monarchical government ; and the beft fitted to preferve the liberties of the people againft the encroachments of the crown. For my part, though I agree with both writers in their obferrations, I muft fay, that the British and Kentifh divifion of Gavel-kind was humane, though it may have been impolitic; and that the Norman fyftem in its confequences, while it freed the people from the tyranny of one, ferved to make them flaves to many.

The Conqueror's laws are publifhed by Dr. Wilkins, as well as Dr. Gale; alfo by Lambert, and others, though Mr. Maferes may probably not have met with thofe editions.

Mr. Whitaker is of a contrary opinion to Mr. Maferes; for Reliefs, \&c. Mr. Whitaker thinks that Relief was known in England before William I, and founds that opinion on the laws of Howel Dha.

I AGREE that in the time of William I, parliaments were compofed of tenants in chief to the king; but they were, I conceive, Tenants in fuch tenants only in chief as held by military fervice. It is faid, indeed, that tenants in chief who held in focage were members of the great council; but herein I muft beg leave to differ; for, tho' $I$ find in the time of the Britons, that the Feud (a Britilh word for Eftate) was held by military fervice, and alfo by focage rents; and though divers inftances are given of fuch holdings, under the Norman kings, yet I think that they appeared in parliament for no other purpofe but to do their duty of counfel, as military tenants, and to affefs what thould be paid by fuch as had been remifs in their duty; and I know not what bufinefs a focage tenant, merely as $\mathrm{Y}$ y 2 fuch, 


\section{Mr. Mellish's Obfervations}

fuch, had to tranfact in parliament. When military tenures were in procefs, of time changed into rents; when fcutages fupplied the place of perfonal fervice, and armies were raifed by indentures in the Exchequer; when fubinfeudations increafed; when reprefentation togk place; the fervice by military tenure was, of courfe, ; and there being fcarce fuch a perfon as a tenant in chief by military fervice, and great alterations in property having been made in a civil war, the legillature thought fit to abolifh the military fervice, I 2 C. IF.

Subinfeudations.

THE effect of Subinfeudations feems only to have made it difficult to know who ought to attend at parliaments; but this difficulty was removed by the Statute 2uia emptores terrarum \&c. and by the mode of reprefentation, which fixed the rights of the voters. The differ- $\quad$ Mr. Maferes has made an accurate diftinction with refpect to
ent parliaments. parliaments; and I am firmly perfuaded with him, that there was an effential difference between the curia de more coadunata (which met regularly at Chriftmas, Eafter, and Whitfuntide, whether the king fummoned them or not) and the conventus principum ex edicto regis. Could we afcertain the practices of antiquity, we fhould find perhaps that this conventus principum was the origin of that great council of peers which met in the times of Charles I, as Clarendon mentions.

Summons to I will not take upon me to fay that there was in thofe early days parliament. a conflant regularity obferved in fummoning to parliament. I have read, though where I cannot at prefent recollect, that even women have been fummoned to parliament.

IN thofe times the rights and prerogatives of the crown were not fo rigoroufly examined ; but if the king oppreffed the nation, an infurrection enfued, which foon convinced him of his error. 
As to Villenages, the proper divifion I apprehend fhould be into Villenage, thofe holden by certain, and thofe by uncertain fervices.

THE Villenages holden by certain bafe fervices are tenants in ancient demefne, or at prefent copyholders, holding according to the cuftom of the manor, but not at the will of the lord [ $l]$. Thefe Villains were known to the ancient Britons, and to the Irifh; tho" Bracton fays they arofe from the Conqueft. He proves they were freemen.

THE Villenages holden by uncertain bafe fervices were called. Pure Villenages; and thefe were holden either by flaves, or freemen. Thofe holden by flaves arofe, I conceive, principally from the Saxon and Danifh conquefts; though fome fuch exifted in the time of the Britons, as. Mr. Whitaker has fhewn; but pure Villenages holden by freemen may have arifen from the Norman conquefts; and Bracton gives the following account of them;

"Item tenementum non mutat fatum liberi magis quain fervi. "Poterit enim liber bomo tenere purum villenagizum faciendo quic" quid ad villanum pertinebit, et nibilo minus liber erit, cum boc fa" " ciat ratione villenagii et non perfonae Juae, et ideo poterit quando. "voluerit villenagium dverere, et liber difcedere, nifillaqueatus fit "per uxorem nativam ad boc faciendum, ad quam ingreflus fuit in "villenagiam et quae praeftare poterit impedimentum."

AND indeed it feems no way improbable that thofe villains whom: Bracton takes notice of (where he is fpeaking of ancient demefne) who had been oufted of their tenements by William the Conqueror, might return, and become tenants upon bafe and certain fervices: but might, from neceffity, take the lands upon the bafeft and moft uncertain fervices.

I wouL $D$ obferve, that villains ratione perfonae might not only be intirely manumitted, but alfo partially privileged from the

[l] Whitaker's Hiftory of Manchefter, p. 206e

feizure: 
feizure of the lord; and this by being profeffed; by being made a knight; by being a prieft in the king's chapel ; a nieve marrying a freeman. \&c. Thefe privileges, however, did not abfolutely manumit $[0]$.

THe form of Manumiffion was thus $[p]$;

Qui fervum fuum liberat in ecclogia, vel mercato, vel comitatu, wil bundredo, coram teftibus, et palam faciat; et liberas ei vias et porias confcribat apertas, et lanceam et gladium, vel qui liberorum wma ei ponat.

BY Manumifion and Infranchifement on the decifion of courts, who were very aftute in their interpretations, pure Villenage ratione perjonae is worn out in England, as in France. The villain acquiring a freedom of perfon foon acquired a property, with which he purchafed from the lord various indulgences, and at laft made eren his tenure certain : for, having gained his freedom, he at firft held, as before, by fervices of the bafeft and moft uncertain tenure; he then altered the tenure to bafe and certain fervices; and then often changed them into a rent; witnefs the Bicton-tenants, and moft of the tenants by ludicrous fervices. Sanctuaries may, in the method Mr. Maferes mentions, have increafed the number of Pure Villains.

Tenants for years.

Burgages.

Bu T I cannot agree with him, that Tenants for Years were other than Freeholders.

I AM of opinion, that the right of the Clergy to taxes of fervants arofe from taxes on flaves; and is not now to be maintained. Some Burgages may have been compofed of Villains, ratione tenementorum; but many, as I take it, ratione perfonarum; and fo far was Nottingham from being in that abject ftate, that the burgeffes of Nottingham had flaves of their own. And by an attefted copy in the hands of Thomas Aftle, Efquire, King John grants for fixtyfix marks to the burgeffes of Derby, a Confirmation of their liber-

[0] I Inft. p. I36. b. s37. b. [p] i Inftit. ib. from Lib. Ruber. c. 78. ties; 
ties; an implication that they were free before King John's Charter. It refers alfo to the rights of Nuttingham tempore Henrici proavi, or Henry $\mathrm{I}$.

TAxes may have been raifed, by arbitary power, oftner on: burgages, than on other tenures; but the burgeffes endeavoured to keep up appearances; they voted firft whether they fhould. fupply the king's wants, and then voted the Quantum of the fupply.

THE privilege of incorporation was rarely granted to others than freemen; including in that idea the pure villains who held Incorporation. ratione tenementorum, under the word freeman, quia potuit villenagium deferere.

I ENTIREI,Y agree with Mr. Maferes that great humanity was in this kingdom thewn to the villain ratione perfonarum.

$I_{T}$ is obferved, that moft of the infranchifements of boroughs happened in the reign of H. II. R. I. John, and H. III. But this fubject has been fo amply treated by Dr. Brady, and ftill more profeffedly by that elaborate antiquary, Mr. Madox, in his Firma Burgi, that there is lefs occafion to enter upon it here.

I ToTALLy agree with Mr. Maferes, that a tenant of the 300 th part of a barony was intitled to fit in parliament; and that hence arofe the divifion into Barones Majores, and Minores; Tenant of 300 th part of Barony. but I do not apprehend that the Barones Minores were fummoned, generally, before Magna Charta; becaure the grievance complained of feems to have been, that the king fummoned efpecially whom he pleafed; and in that ftatute it is expreffly fipulated that the king thall fend fpecial writs to every greater baron; and thall fummon the Barones Minores by a general writ directed to the Mheriff. 
'THE remarks on the extent of manors in the appendix are very curious. I fear I need an apology for an intrufion, from which you are not likely to derive much information or pleafure; but I thought the fubject interefting, and wifhed that fome gentleman of more adequate abilities might purfue the ftudy, and throw freth light upon this important fubject.

TRUTH will ever bear the ftricteft forutiny : and that excellent conftitution, which has been refined and purified from its drofs by the experience of ages, will come forth ftill more perfect when its ancient ufages are inquired into under the infpection of this learned Society.

I am,

SIR,

Your obliged fervant,

Charles Mellifh. 